\title{
A new sawfly of Megalodontesidae (Insecta, Hymenoptera, Pamphilioidea) with pectinate antennae from the Early Cretaceous of China
}

\author{
Yimo Wang', Mei Wang ${ }^{2}$, Chungkun Shih ${ }^{1,3}$, Alexandr P. Rasnitsyn ${ }^{4,5}$ Jun Yao ${ }^{6}$, \\ Dong Ren', Taiping Gao'
}

I College of Life Sciences and Academy for Multidisciplinary Studies, Capital Normal University, 105 Xisanhuanbeilu, Haidian District, Beijing 100048, China 2 Key Laboratory of Forest Protection, State Forestry Administration, Research Institute of Forest Ecology, Environment and Protection, Chinese Academy of Forestry, Beijing 100091, China 3 Department of Paleobiology, National Museum of Natural History, Smithsonian Institution, Washington, DC, 20013-7012, USA 4 Palaeontological Institute, Russian Academy of Sciences, 117868, Moscow, Russia 5 The Natural History Museum, Cromwell Road, London SW7 5BD, UK 6 Institute of Apicultural Research of CAAS, No. 1 Beigou Xiangshan, Haidian District, Beijing 100093, China

Corresponding author: Taiping Gao (tpgao@cnu.edu.cn)

Academic editor: S. M. Blank | Received 24 July 2019 | Accepted 9 November 2019 | Published 2 December 2019

http://zoobank.org/9583B43B-9F84-4975-96B5-F3A0050F2E21

Citation: Wang Y, Wang M, Shih C, Rasnitsyn AP, Yao J, Ren D, Gao T (2019) A new sawfly of Megalodontesidae (Insecta, Hymenoptera, Pamphilioidea) with pectinate antennae from the Early Cretaceous of China. ZooKeys 893: 115-123. https://doi.org/10.3897/zookeys.893.38512

\begin{abstract}
A new sawfly of Megalodontesidae, Jibaissodes peichenae sp. nov., is described from the Lower Cretaceous Yixian Formation of Northeastern China. It is established mainly based on the pectinate antenna comprising 42 flagellomeres and the proximal 28 bearing apical rami, which gradually shorten in length toward the apex of the flagellum. The pterostigma of the forewing is infuscated apically and on the hind wing, vein 1 -Rs is nearly equal to $1 \mathrm{r}-\mathrm{m}$ and slightly shorter than $1-\mathrm{M}$. The first tergum is widely excised posteriorly and roundly protruding laterally alike in Megalodontes. This find supports that pectinate antennae in extant sawflies of Megalodontesidae originated at least during or before the Early Cretaceous.
\end{abstract}

\section{Keywords}

ramified antennae, Symphyta, taxonomy, Yixian Formation

Copyright Yimo Wang et al. This is an open access article distributed under the terms of the Creative Commons Attribution License (CC BY 4.0), which permits unrestricted use, distribution, and reproduction in any medium, provided the original author and source are credited. 


\section{Introduction}

Megalodontesidae is a small extant family with only one extant genus comprising 42 species and 12 fossil genera with 23 species (Taeger et al. 2018). Megalodontesidae comprises four subfamilies: three extinct subfamilies, Archoxyelydinae Wang, Rasnitsyn \& Ren, 2013, Decorisiricinae Wang, Rasnitsyn, Shih, Sharkey \& Ren, 2015, and Praesiricinae Rasnitsyn, 1968 and one extant subfamily, Megalodontesinae Konow, 1897. The sole extant genus, Megalodontes Latreille, 1803, which is distributed in temperate regions of the Palaearctic (Benson 1968; Goulet 1993; Blank et al. 2001; Taeger et al. 2010), and an extinct genus, Jibaissodes Ren, Lu, Guo \& Ji, 1995, are characterized by having saw-like or comb-like ramified antennae.

Among extant symphytan insects, ramified antennae are present in various taxa, i.e., in Diprionidae, Pergidae, Tenthredinidae, and Megalodontesidae (Gao et al. 2016). Fossil records of 'Symphyta' with ramified antennae are very rare. Up to date, only two species with ramified antennae have been reported: Jibaissodes bellus Gao, Shih Labandeira, Santiago-Blay, Yao \& Ren, 2016 with simply ramified antennae from the Lower Cretaceous Yixian Formation, and Atefia rasnitsyni Krogmann, Engel, Bechly \& Nel, 2012 with the biflabellate antennae from the Lower Cretaceous Crato Formation, assigned to the superfamily Tenthredinoidea s. str. Latreille, 1802. The occurrence of biflabellate antennae in $A$. rasnitsyni has been suggested to indicate the antiquity of insect usage of long-range female attractants (Krogmann et al. 2013).

In this paper, we describe Jibaissodes peichenae sp. nov. based on a well-preserved specimen from the mid-Lower Cretaceous Yixian Formation of northeastern China. The new species with distinctly pectinate antennae contributes additional important morphological characters of the family Megalodontesidae.

\section{Material and methods}

For the paper we examined the holotypes of Jibaissodes peichenae sp. nov. (specimen no. CNU-HYM-LB2018033, part and counterpart) and Jibaissodes bellus Gao, Shih, Labandeira, Santiago-Blay, Yao \& Ren, 2016 (specimen no. CNU-HYM-LB2011009, part and counterpart), which are housed in the Key Laboratory of Insect Evolution and Environmental Changes at the Capital Normal University, Beijing, China (CNUB; Dong Ren, curator). Both were collected from the mid-Lower Cretaceous Yixian Formation of Liaoning Province of China. The holotype of Jibaissodes giganteus Ren, Lu, Guo \& Ji, 1995 (specimen no. BL92105, part, housed in the Geological Museum of China, Beijing, China, Jun Yao, curator) was also examined and redrawn for this paper. It was collected from the Lower Cretaceous Lushangfen Formation of Beijing of China.

The specimens were examined and photographed, either dry or wetted with $95 \%$ ethanol, by using a Nikon SMZ25 with an attached camera system. Line drawings were prepared using Adobe Illustrator CC and Adobe Photoshop CC graphics software. The wing venation nomenclature used in the paper was modified after Rasnitsyn (1969, 1980). 


\section{Taxonomy}

\section{Genus Jibaissodes Ren, Lu, Guo \& Ji, 1995}

Emended diagnosis. Mesonotum large, notauli strongly impressed, tapering to acutely rounded base. Forewing veins $1-\mathrm{Rs}$ and $1-\mathrm{M}$ nearly in straight line; $1 \mathrm{r}$-rs present, shorter than 2r-rs; $1 \mathrm{r}$-rs reclival and $2 \mathrm{r}$-rs proclival; $1 \mathrm{~m}$-cu near base of cell $2 \mathrm{rm}$; $1 \mathrm{cu}-\mathrm{a}$ at base of cell $1 \mathrm{mcu}$, connecting to juncture of $\mathrm{M}+\mathrm{Cu}$; cell $1 \mathrm{mcu}$ small, nearly rectangular; cell $2 \mathrm{rm}$ longer than cell $3 \mathrm{rm}$. Hind wing with $1-\mathrm{Cu}$ nearly perpendicular to cu-a; $1 \mathrm{~A}$ and $2 \mathrm{~A}$ strongly curved.

Type species. Jibaissodes giganteus Ren, Lu, Guo \& Ji, 1995

Emended description. Fossil incomplete: head appendages, pronotum, legs, abdomen and supposedly posterior parts of wings missing. Head moderately large, near oval; compound eyes large; ocelli not visible. Mesonotum broader than long; mesoscutum small, with distinct medial line and impressed notauli; mesoscutellum indistinct; metanotum narrow and long; metascutum with cenchri present but indistinct. Forewing (Fig. 1E) with Sc absent; pterostigma long, completely infuscated; 1-Rs reclival, slightly shorter than 1-M; 1-M long and straight; Rs-M juncture nearly straight; Rs+M straight, forming a nearly straight line with $2-\mathrm{M}$, nearly perpendicular to $1-\mathrm{M}$; $1 \mathrm{r}$-rs slightly shorter than $2 \mathrm{r}$-rs; $2 \mathrm{r}$-rs distinctly proclival, positioned near distal 0.75 of pterostigma; $1 \mathrm{cu}-\mathrm{a}$ straight, distinctly bent towards wing tip; $\mathrm{M}+\mathrm{Cu}$ straight; $1-\mathrm{Cu}$ and 2-Cu curved, $1-\mathrm{Cu}$ nearly equal to $2-\mathrm{Cu}$; $2 \mathrm{r}-\mathrm{m}$ straight and reclival; $3 \mathrm{r}-\mathrm{m}$ straight towards wing tip; 1 A slightly curved. Costal cell slightly widened before point of origin of Rs; cell $2 \mathrm{rm}$ distinctly longer than cell $3 \mathrm{rm}$, cell $3 \mathrm{rm}$ trapezoid; cell $1 \mathrm{mcu}$ small, nearly rectangular; cell $2 \mathrm{mcu}$ large, pentagonal. Hind wing (Fig. 1F) with 1 -Rs very short, $1 \mathrm{r}-\mathrm{m}$ straight; $1 \mathrm{r}-\mathrm{m}$ and $1-\mathrm{M}$ forming a straight line. $\mathrm{M}+\mathrm{Cu}$ slightly bent; 1-Cu slightly curved, nearly perpendicular to cu-a; cu-a nearly straight; vein $1 \mathrm{~A}$ strongly arched.

Other species included. Jibaissodes bellus Gao, Shih, Labandeira, Santiago-Blay, Yao \& Ren, 2016; Jibaissodes peichenae sp. nov.

\section{Jibaissodes peichenae Wang, Shih \& Gao, sp. nov.} http://zoobank.org/D752BA0D-21EF-44AB-BBC7-B9E4279A6883 Figs $1-3$

Type material. Holotype, specimen no. CNU-HYM-LB2018033p/c, part and counterpart.

Diagnosis. Antenna pectinate, with 42 flagellomeres, flagellum longer than head width, proximal 28 flagellomeres with apical rami, rami gradually shortening in length toward apex of flagellum; scape almost 3 times as long as first flagellomere. Anterior margin of pronotum round, with weakly concave posterodorsal margin. Forewing with pterostigma infuscated apically; vein $1 \mathrm{cu}-\mathrm{a}$ strongly curved. Hind wing vein 1-Rs nearly equal to $1 \mathrm{r}-\mathrm{m}$, slightly shorter than $1-\mathrm{M}$. 

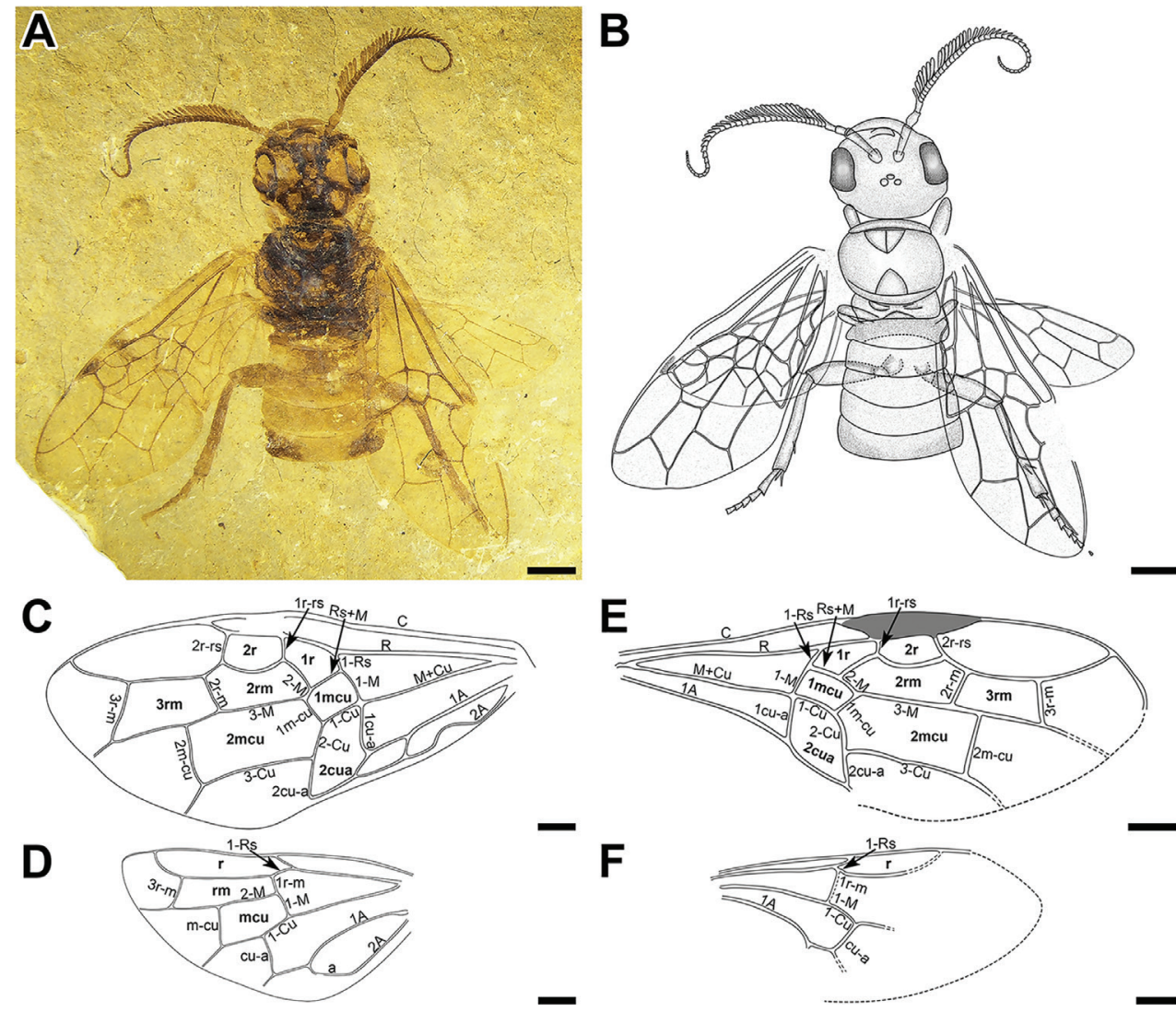

Figure I. A-D Jibaissodes peichenae sp. nov., holotype, part: A photograph of complete specimen B line drawing of complete specimen $\mathbf{C}$ line drawing of forewing $\mathbf{D}$ line drawing of hind wing $\mathbf{E}, \mathbf{F}$ Jibaissodes giganteus, holotype: $\mathbf{E}$ line drawing of forewing $\mathbf{F}$ line drawing of hind wing. Scale bars: $2 \mathrm{~mm}(\mathbf{A}, \mathbf{B})$, $1 \mathrm{~mm}(\mathbf{C}-\mathbf{F})$.

Description. Body (Figs 1A, B, 3A). Fossil incomplete: distal abdominal segments missing, part of the legs invisible. Middle and surrounding regions of compound eyes and part of posterior head pale, remainder of head dark. Thorax and legs entirely or predominantly dark. First tergum except hind margin and fifth tergum laterally dark. Body about $14.9 \mathrm{~mm}$ (but distal abdominal segments missing), antenna $11.4 \mathrm{~mm}$ long; forewing about $13.6 \mathrm{~mm}$ in length, maximum width $6.0 \mathrm{~mm}$; hind wing about $8.5 \mathrm{~mm}$ in length, maximum width $3.8 \mathrm{~mm}$.

Head. Large, about as wide as thorax. Head (Fig. 2A) $5.3 \mathrm{~mm}$ wide and $4.6 \mathrm{~mm}$ long, almost circular. Compound eyes $1.8 \mathrm{~mm}$ long, $1.1 \mathrm{~mm}$ wide; right mandible large, bent and sickle-shaped; antenna (Fig. 2D, E) with 42 flagellomeres, basal 28 flagellomeres with rami extending from apicolateral angle, apical 14 flagellomeres without distinct rami, longest ramus about $0.8 \mathrm{~mm}$ in length, longest ramus slightly longer than total length of following three flagellomeres; rami gradually shortening in length toward apex of flagellum, first flagellomere much shorter than scape, $0.3 \mathrm{~mm}$ wide, $0.5 \mathrm{~mm}$ long; scape 1.4 $\mathrm{mm}$ long, maximum $0.4 \mathrm{~mm}$ in width; pedicel $0.8 \mathrm{~mm}$ long, maximum $0.5 \mathrm{~mm}$ wide. 

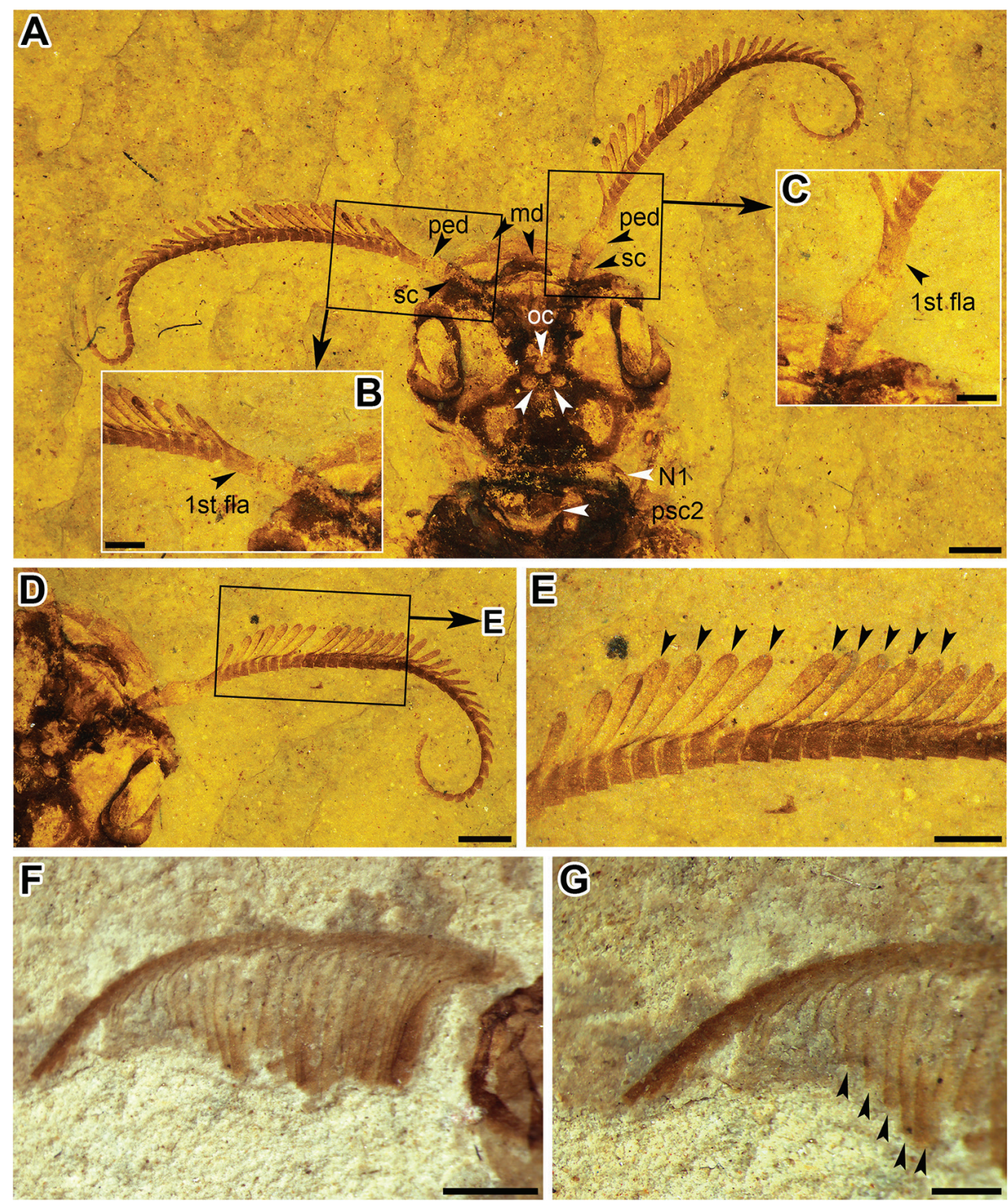

Figure 2. A-E Jibaissodes peichenae sp. nov., holotype, part: A head B basis of left antenna $\mathbf{C}$ basis of right antenna $\mathbf{D}$ right antenna $\mathbf{E}$ basal to middle section of right antenna $\mathbf{F}$, $\mathbf{G}$ Jibaissodes bellus, holotype: $\mathbf{F}$ right antenna $\mathbf{G}$ apical portion of right antenna. Abbreviations: $\mathrm{md}=$ mandible, sc = scape, ped $=$ pedicel, oc $=$ ocelli, 1 st fla $=1$ st flagellomere, $\mathrm{N} 1=$ pronotum, psc2 $=$ mesoscutum. Scale bars: $1 \mathrm{~mm}$ (A, D, F, G); $0.5 \mathrm{~mm}(\mathbf{B}, \mathbf{C}, \mathbf{E})$.

Thorax. Maximum width $4.9 \mathrm{~mm}$; pronotum short, apex round, with weakly concave posterodorsal margin. Mesoscutum large, with medial line and notauli strongly impressed, tapering to acutely rounded base; mesoscutum without line to mesoscutellum; mesoscutellum tapering to acutely sharp apex; metascutum with 
cenchri present and small. Metatibia (Fig. 3B, C) with two preapical (near distal 0.7 of length) and two apical spurs; metabasitarsus long but shorter than remaining tarsomeres combined; metafemur, metatibia, and metabasitarsus lengths $3.4 \mathrm{~mm}$, $4.6 \mathrm{~mm}$, and $1.1 \mathrm{~mm}$, respectively.

Abdomen. Five visible segments preserved; maximum width about $5.3 \mathrm{~mm}$; first tergum medially undivided, posteriorly widely excised, laterally roundly protruding, medio-anteriorly dark; fifth tergum laterally dark.

Forewing. (Fig. 1B, C) Wing membrane mostly hyaline with weakly infuscated bands covering base and middle regions of forewing, surrounding veins $\mathrm{R}, \mathrm{M}+\mathrm{Cu}$, 1r-rs, 2-M, m-cu, and 2-Cu; R slightly thickened before pterostigma; pterostigma infuscated apically; 1 -Rs (0.5 mm long) short and reclival; 1-M (1.0 mm long) long and slightly curved, about twice as long as 1-Rs; Rs+M straight; $1 \mathrm{r}-\mathrm{rs}$ length $0.7 \mathrm{~mm}$, slightly shorter than 2r-rs, $0.8 \mathrm{~mm}$ long; 2r-rs slightly proclival, positioned near $3 / 4$ pterostigma; $1 \mathrm{cu}-\mathrm{a}$ distinctly bent towards wing base, $1.4 \mathrm{~mm}$ in length; $\mathrm{M}+\mathrm{Cu}$ nearly straight; $1 \mathrm{~m}-\mathrm{cu} 0.8 \mathrm{~mm}$ long, 0.7 times as long as $1-\mathrm{Cu}(1.1 \mathrm{~mm}$ long); $1-\mathrm{Cu}$ nearly equal to $2-\mathrm{Cu}$ ( $1 \mathrm{~mm}$ long) in length; $2 \mathrm{r}-\mathrm{m}$ slightly curved and reclival; $3 \mathrm{r}-\mathrm{m}$ straight towards wing tip; $2 \mathrm{~A}$ with shallow arch midway before $1 \mathrm{a}-2 \mathrm{a}$ cross-vein. Costal cell widened at point of origin of 1-Rs; cell $1 \mathrm{r}$ nearly equal in size to cell $2 \mathrm{r}$; cell $2 \mathrm{rm}$ longer than cell $3 \mathrm{rm}$, cell $3 \mathrm{rm}$ trapezoid; cell $1 \mathrm{mcu}$ small, nearly rectangular; cell $2 \mathrm{mcu}$ large, pentagonal.

Hind wing. (Fig. 1B, D) 1-Rs (0.5 mm long) nearly equal to $1 \mathrm{r}-\mathrm{m}(0.5 \mathrm{~mm}$ long), shorter than 1-M (0.7 mm long), 1r-m straight; $1 \mathrm{r}-\mathrm{m}$ and 1-M forming a nearly straight line; $3 \mathrm{r}-\mathrm{m}$ present, $0.9 \mathrm{~mm}$ in length, strongly bent towards wing tip; $1 \mathrm{~m}$-cu (1.0 mm long) and cu-a (1.1 mm long) present, longer than $3 \mathrm{r}-\mathrm{m}$, cu-a distinctly bent; $\mathrm{M}+\mathrm{Cu}$ nearly straight; vein $1 \mathrm{~A}$ strongly arched.

Gender. Unknown.

Remarks. The species can be assigned to Jibaissodes according to the following diagnostic characters: forewing vein $1 \mathrm{r}$-rs present, shorter than $2 \mathrm{r}-\mathrm{rs}$, cell $2 \mathrm{rm}$ longer than 3rm and cell $1 \mathrm{mcu}$ small. Jibaissodes was described from a poorly preserved fossil specimen with a left and a right forewing, a right hind wing, and parts of head and thorax (Ren et al. 1995). Jibaissodes peichenae sp. nov. is distinctly differentiated from the type species of J. giganteus by the following characters: forewing with pterostigma not completely infuscated; forewing vein 3r-m distinctly longer than $2 \mathrm{r}-\mathrm{m}$ (about 1.7 times as long as 2r-m); 1cu-a distinctly curved; and hind wing vein 1-Rs nearly equal to $1 \mathrm{r}-\mathrm{m}$. Furthermore, J. peichenae is distinguished from J. bellus by the following characters: antenna pectinate, rami short (vs rami long in J. bellus); forewing with pterostigma infuscated apically (vs infuscated medially and apically in J. bellus).

Distribution. Huangbanjigou, near Chaomidian Village, in Shangyuan County, adjacent to Beipiao City, in Liaoning Province of China. Collected from the midLower Cretaceous Yixian Formation, dated as latest Barremian to earliest Aptian, 125 Ma (Ren et al. 1995; Wang et al. 2015).

Etymology. The species epithet is dedicated to Miss Peichen Yao, the daughter of Dr Jun Yao, the specimen donator. 

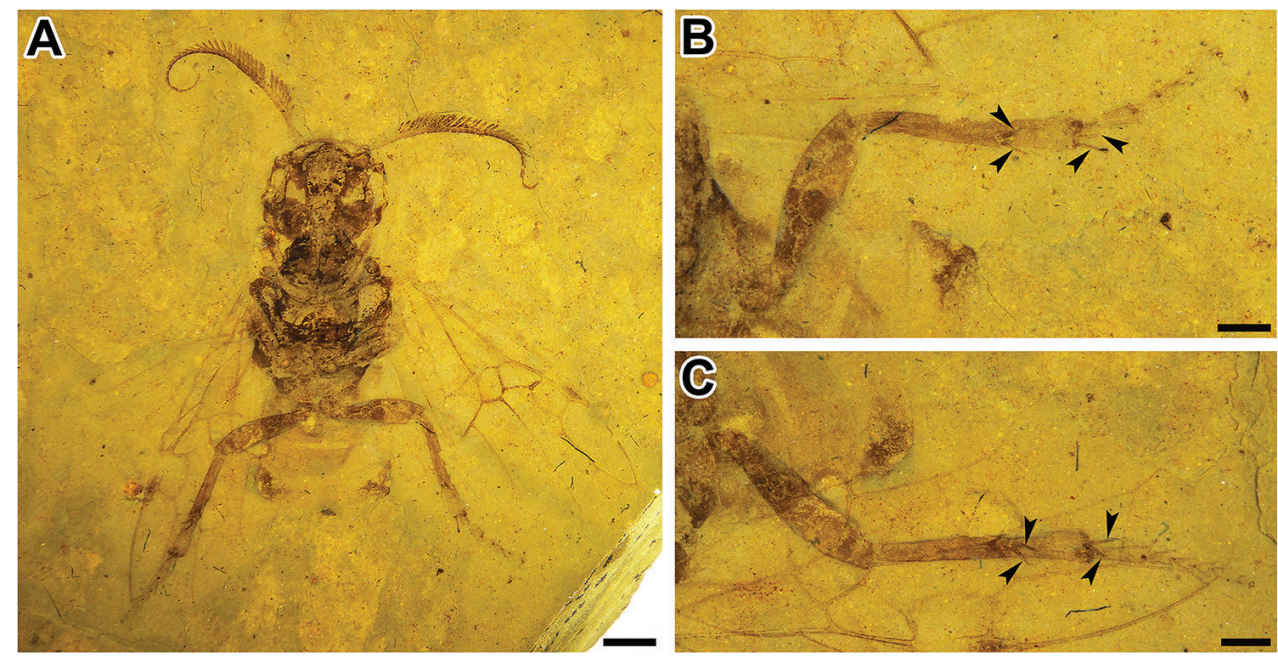

Figure 3. Jibaissodes peichenae sp. nov., holotype, counterpart A complete specimen B right hind leg C left hind leg. Arrows indicate spurs. Scale bars: $2 \mathrm{~mm}(\mathbf{A}) ; 1 \mathrm{~mm}(\mathbf{B}, \mathbf{C})$.

\section{Discussion}

Jibaissodes peichenae sp. nov. is assigned to Megalodontesidae by two features typical for Megalodontesidae: undivided first tergum and absent Sc (Benson 1968; Goulet 1993; Wang et al. 2016). In addition, J. peichenae can be attributed to Megalodontesinae, by the pectinate antennae as a derived character state. Other fossil Megalodontesidae, i.e., Decorisiricinae, Archexyelinae, and Praesiricinae, have a synantennomere 3 (Blank et al. 2013) like the ancestral Xyelidae and a number of fossil taxa, which represents an ancestral character of Hymenoptera (e.g., Rasnitsyn 1996). The semicircular distal excision and the lateral round protuberances of the first abdominal tergum is a putative apomorphy of Jibaissodes + Megalodontes, since protrusions are obviously absent in Decorisiricinae, Archexyelinae, and Praesiricinae. On the forewing, $\mathrm{M}+\mathrm{Cu}$ is straight, while it is curved in Archexyelinae and Praesiricinae.

All fossil megalodontesids share as a plesiomorphy of a curved vein $2 \mathrm{~A}$ on the forewing (Wang et al. 2015, 2016). The almost straight 2A of the extant Megalodontes is an apomorphy of this taxon (Taeger 2002; Taeger et al. 2014). Therefore, we treat Jibaissodes and Megalodontes as separate groups. Although J. peichenae sp. nov. shares two features with Megalodontes (pectinate antennae and laterally protruding, medio-anteriorly dark first tergum; Taeger 2002), it is impossible to evaluate the coloration of head, pronotum, and mesonotum of $J$. peichenae as preserved on fossil with certainty. We need more fossil specimens to address whether Jibaissodes has close affinities with Megalodontes.

Since weak sexual dimorphism has been observed within several groups of Megalodontes having antennae with relatively long rami in males and slightly short rami in females (Taeger 2002), and thereby, we cannot rule out the possibility that these two species, J. peichenae with long ramified antennae and J. bellus with short ramified an- 
tennae, might be different sexes of the same species. However, J. peichenae differs from $J$. bellus also in the following characters: pterostigma of forewing infuscated apically and, particularly, the excised posterior edge of first tergum, which is more similar to Megalodontes (Taeger 2002; Taeger et al. 2014). Given that the holotype of J. peichenae lacks the tip of the abdomen, it is impossible to properly ascertain whether the two should be considered as the same species. Therefore, we treat them as separate for now, pending future finds of additional fossil specimens to confirm the relationship between these two species.

\section{Acknowledgements}

We are very grateful to Dr Xiaodan Lin and Mr Xiangbo Guo (College of Life Sciences, Capital Normal University) for their help in this research. We thank the Editorial Board of ZooKeys, and in particular, Dr Stephan M. Blank. We express our gratitude to Dr Lars Vilhelmsen, Dr Andreas Taeger, and Dr Meicai Wei for their critical but valuable reviews of the manuscript. We also thank the curator of the type specimen of Jibaissodes giganteus, Dr Jun Yao. This project was supported by grants to D.R. from the National Natural Science Foundation of China (grant nos. 31730087 and 41688103). T.P.G. was supported by the Program for Changjiang Scholars and Innovative Research Team in University (IRT-17R75), Project of High-level Teachers in Beijing Municipal Universities (grant no. IDHT20180518) and the Support Project of High-level Teachers in Beijing Municipal Universities in the Period of $13^{\text {th }}$ Five-year Plan (CIT\&TCD201704090). M.W. was supported by Fundamental Research Funds of CAF (No. CAFYBB2019QB004) and the National Natural Science Foundation of China (grant no. 31702038). The authors declare that there are no competing interests in the manuscript.

\section{References}

Benson RB (1968) Hymenoptera from Turkey, Symphyta. Bulletin of the British Museum (Natural History) 22: 111-207. https://doi.org/10.5962/bhl.part.9952

Blank SM, Deters S, Drees M, Jänicke M, Jansen E, Kraus M, Liston AD, Ritzau C, Taeger A (2001) Symphyta. In: Dathe, HH, Taeger A, Blank SM (Eds) Verzeichnis der Hautflügler Deutschlands (Fauna Germanica 4). Entomologische Nachrichten und Berichte, Beiheft 7: 8-27.

Blank SM, Shinohara A, Altenhofer E (2013) The Eurasian species of Xyela (Hymenoptera, Xyelidae): taxonomy, host plants and distribution. Zootaxa 3629: 1-106. https://doi. org/10.11646/zootaxa.3629.1.1

Gao TP, Shih CK, Labandeira CC, Santiago-Blay JA, Yao YZ, Ren D (2016) Convergent evolution of ramified antennae in insect lineages from the early Cretaceous of northeastern China. Proceedings of the Royal Society B: Biological Sciences 283: 20161448. https:// doi.org/10.1098/rspb.2016.1448 
Goulet H (1993) Superfamilies Cephoidea, Megalodontoidea, Orussoidea, Siricoidea, Tenthredinoidea, and Xyeloidea. In: Goulet H, Huber JT (Eds) Hymenoptera of the World: an Identification Guide to Families. Agriculture Canada, Ottawa, 101-129.

Krogmann L, Engel MS, Bechly G, Nel A (2013) Lower Cretaceous origin of long-distance mate finding behaviour in Hymenoptera (Insecta). Journal of Systematic Palaeontology 11: 83-89. https://doi.org/10.1080/14772019.2012.693954

Rasnitsyn AP (1969) Origin and evolution of the lower Hymenoptera. Transactions of the Paleontological Institute, Academy of Sciences of the USSR 123: 1-196 [in Russian]

Rasnitsyn AP (1980) Origin and evolution of the Hymenoptera. Transactions of the Paleontological Institute, Academy of Sciences of the USSR 174: 1-192 [in Russian]

Rasnitsyn AP (1996) Conceptual issues in phylogeny, taxonomy, and nomenclature. Contributions to Zoology 66: 3-41. https://doi.org/10.1163/26660644-06601001

Ren D, Lu LW, Guo ZG, Ji SA (1995) Faunae and Stratigraphy of Jurassic-Cretaceous in Beijing and the Adjacent Areas. Seismic Publishing House, Beijing, 43 pp.

Taeger A (2002) The Megalodontesidae of Europe (Hymenoptera, Symphyta). Sawflies (Hymenoptera: Symphyta). A Review of the Suborder, the Western Palaearctic taxa of Xyeloidea and Pamphilioidea. Tremex, Helsinki, 461-480.

Taeger A, Blank SM, Liston AD (2010) World catalog of Symphyta (Hymenoptera). Zootaxa 2580: 1-1064. https://doi.org/10.11646/zootaxa.2580.1.1

Taeger A, Paris M, Nieves-Aldrey JL (2014) The type specimens of sawflies (Hymenoptera: Symphyta) of the Museo Nacional de Ciencias Naturales, Madrid. Zootaxa 3790: 103138. https://doi.org/10.11646/zootaxa.3790.1.5

Taeger A, Liston AD, Prous M, Groll EK, Gehroldt T, Blank SM (2018) ECatSym - Electronic World Catalog of Symphyta (Insecta, Hymenoptera). Program version 5.0 (19 Dec 2018), data version 40 (23 Sep 2018). Senckenberg Deutsches Entomologisches Institut (SDEI), Müncheberg. https://sdei.de/ecatsym/ [Accessed on: 2019-11-12]

Wang M, Rasnitsyn AP, Shih CK, Ren D (2015) New xyelydid sawflies from the Lower Cretaceous of China. Cretaceous Research 5: 169-178. https://doi.org/10.1016/j.cretres.2014.12.008

Wang M, Rasnitsyn AP, Shih CK, Sharkey JM, Ren D (2016) New fossils from China elucidating the phylogeny of Praesiricidae (Insecta: Hymenoptera). Systematic Entomology 41: 41-55. https://doi.org/10.1111/syen.12142 